\title{
Faktor-Faktor yang Mempengaruhi Penerapan Panca Usahatani Padi Ladang Amfibi pada Petani Binaan Balai Pengkajian Teknologi Pertanian di Kabupaten Manokwari
}

\section{Galih Wahyu Hidayat ${ }^{1 *}$}

${ }^{1}$ Balai Pengkajian Teknologi Pertanian Papua Barat

\begin{tabular}{l}
\hline \multicolumn{1}{c}{ ARTIKEL INFO } \\
\hline Sejarah artikel \\
Diterima 30/04/2021 \\
Diterima dalam bentuk revisi $06 / 05 / 2021$ \\
Diterima dan disetujui 30/05/2021 \\
Tersedia online 22/06/2021 \\
\hline Kata kunci \\
Faktor berpengaruh \\
Penerapan \\
Pasca usahatani \\
Padi ladang amfibi \\
\hline
\end{tabular}

\begin{abstract}
ABSTRAK
Padi ladang merupakan komoditas potensial untuk dikembangkan karena luas lahan kering yang tinggi di Kabupaten Manokwari. BPTP Papua Barat melaksanakan pengembangan padi ladang amfibi sejak 2018 karena varietas padi ini memiliki kemampuan bertahan pada kondisi genangan air maupun dalam kondisi lahan yang kering. Padi amfibi merupakan padi baru di Kabupaten Manokwari dengan berbagai kelebihan yang menguntungkan apabila dibandingkan dengan padi yang sudah ditanam turun-temurun oleh petani. Penerapan panca usahatani padi ladang amfibi terdiri dari lima komponen yaitu: a). penggunaan benih unggul, b). pengolahan lahan, c). irigasi atau ketercukupan air, d). pemupukan berimbang dan e). pengendalian hama penyakit. Hasil evaluasi menunjukkan bahwa petani sudah mengikuti rekomendasi dalam menggunakan benih unggul dan mempertimbangkan kecukupan air sebesar $100 \%$ atau diterapkan sepenuhnya. Komponen pengolahan lahan diterapkan $50 \%$, pemupukan berimbang diterapkan $62 \%$ dan pengendalian hama penyakit diterapkan $62 \%$. Kegiatan yang dilaksanakan oleh BPTP ini didukung oleh petani lokal dan petani transmigran yang menanam padi ladang. Produksi dan produktivitas yang dihasilkan petani diharapkan dapat meningkat dengan menerapkan panca usahatani padi ladang amfibi yang direkomendasikan. Penelitian ini dilaksanakan bertujuan untuk menganalisis faktor-faktor yang mempengaruhi penerapan panca usahatani padi ladang amfibi. Hasil penelitian menunjukkan bahwa penerapan panca usahatani termasuk dalam kategori sedang karena dipengaruhi oleh faktor pendidikan, modal usahatani, frekuensi penyuluhan, ketersediaan lembaga keuangan dan sosial budaya.
\end{abstract}

(C) 2021 Politeknik Pembangunan Pertanian Manokwari 


\section{ABSTRACT}

Field rice is a potential commodity to be developed because of the high dry land area in the Manokwari Regency. West Papua AIAT has been developing Amphibian field rice since 2018 because this rice variety can withstand waterlogged conditions and dryland conditions. Amphibian rice is a new rice paddy in Manokwari Regency with various advantages that are beneficial when compared to rice that has been planted from generation to generation by farmers. The application of five amphibian field rice farming consists of five components, namely: a). use of superior seeds, $b$ ). land cultivation, $c$ ). irrigation or water adequacy, $d$ ). balanced fertilization and e). pest control. The results of the evaluation showed that the farmers had followed the recommendations for using superior seeds and had considered water adequacy at $100 \%$

\section{PENDAHULUAN}

Luas panen padi ladang Kabupaten Manokwari sebesar 36,06\% dan merupakan luas panen terluas dibandingkan kabupaten lain di Provinsi Papua Barat. Produktivitas padi ladang pada tahun 2017 adalah 2,6 ton/Ha. Luas lahan kering yang ditanami padi ladang baru sebesar 7\% dari total luas wilayah lahan kering di Kabupaten Manokwari (BPS, 2018).

Komoditas padi sangat berarti bagi masyarakat di Kabupaten Manokwari karena merupakan jenis konsumsi utama dibandingkan sumber karbohidrat lain dan permasalahannya adalah produktivitas padi yang masih rendah untuk mencukupi kebutuhan masyarakat (Sitohang et al., 2014)

Peningkatan jumlah penduduk di Kabupaten Manokwari menjadikan kebutuhan konsumsi beras sebagai bahan pangan yang utama masyarakat juga meningkat. Peningkatan produktivitas padi menjadi kunci untuk memenuhi kebutuhan konsumsi masyarakat or were fully implemented. The land management component is applied $50 \%$, balanced fertilization is applied $62 \%$ and pest control is applied $62 \%$. The activity carried out by BPTP is supported by local farmers and transmigrant farmers who grow upland rice. It is hoped that the production and productivity produced by farmers can increase by implementing the five recommended farming fields of Amphibian rice. This research was carried out aimed at analyzing the factors that influence the application of five amphibian field rice farming. The results showed that the application of five farms was in the moderate category because it was influenced by factors of education, farming capital, frequency of counseling, availability of financial and sociocultural institutions.

tersebut. Balitbangtan telah menghasilkan inovasi berupa 12 varietas padi yang dapat digolongkan sebagai padi ladang jenis amfibi karena kemampuannya untuk bertahan hidup dan tetap berproduksi pada kondisi genangan air maupun kondisi lahan kering. Padi ladang amfibi ini diharapkan dapat menjawab permasalahan kebutuhan konsumsi masyarakat yang tinggi dan ketersediaan lahan kering yang cukup luas di Kabupaten Manokwari.

BPTP (Balai Pengkajian Teknologi Pertanian) Provinsi Papua Barat memiliki tugas untuk mendiseminasikan atau menyebarluaskan inovasi teknologi pertanian yang dihasilkan. Inovasi teknologi Varietas Unggul Baru (VUB) padi ladang amfibi dapat meningkatkan produktivitas. Padi ladang amfibi didiseminasikan kepada petani melalui kegiatan kaji terap yang dilaksanakan pada tahun 2018 di Kabupaten Manokwari. Padi amfibi merupakan padi baru di Kabupaten Manokwari dengan berbagai kelebihan yang menguntungkan 
apabila dibandingkan dengan padi yang sudah ditanam turun-temurun oleh petani. Kegiatan yang dilaksanakan BPTP didukung oleh petani lokal dan petani transmigran yang menanam padi ladang di Kabupaten Manokwari.

Selisih produktivitas padi lading amfibi dengan padi yang ditanam masyarakat sebelumnya adalah sebesar 1,8 ton sampai dengan 2,8 ton per hektar. Data tersebut mempertegas bahwa padi ladang amfibi sangat potensial untuk dikembangkan. Padi ladang amfibi dapat dikembangkan sesuai dengan teknologi yang sudah direkomendasikan di masyarakat Kabupaten Manokwari (Konyep dan Hidayat, 2017).

Pengembangan padi ladang amfibi di Kabupaten Manokwari sudah dimulai sejak tahun 2018 dengan menerapkan 5 komponen rekomendasi teknologi yang sesuai dalam panca usahatani yaitu: a). penggunaan benih unggul, b). pengolahan lahan, c). irigasi atau ketercukupan air, d). pemupukan dan e). pengendalian hama penyakit. Penerapan teknologi panca usahatani oleh petani akan meningkatkan hasil produksi padi ladang amfibi.

Penerapan panca usahatani padi ladang amfibi dilaksanakan dan dikawal oleh petugas penyuluh pertanian lapangan Kabupaten Manokwari. Petani diharapkan mengikuti rekomendasi dan arahan dari petugas pada setiap tahapan penanaman. Tingkat penerapan panca usahatani padi ladang amfibi oleh petani dipengaruhi oleh dua faktor yaitu faktor internal dan eksternal. Faktor internal yang ada dalam diri petani berupa usia, pendidikan, jenis kelamin, luas lahan dan modal usahatani. Faktor eksternal yang mempengaruhi petani adalah frekuensi penyuluhan pertanian, ketersediaan lembaga keuangan, peranan kelompok petani dan sosial budaya. Secara keseluruhan faktorfaktor tersebut akan mempengaruhi hasil produksi dan penerimaan petani padi ladang amfibi. Pengaruh dari masing-masing perlu diketahui dan di analisis sejauh mana terhadap penerapan panca usahatani yang direkomendasikan oleh BPTP Papua Barat.

Berdasarkan uraian latar belakang tersebut dirumuskan permasalahan penelitian yaitu faktor-faktor apa saja yang mempengaruhi penerapan panca usahatani padi ladang amfibi. Penelitian ini akan menunjukkan dan menganalisis faktor-faktor yang mempengaruhi penerapan panca usahatani padi ladang amfibi. Diduga penerapan panca usahatani padi ladang amfibi dipengaruhi oleh faktor usia, pendidikan, jenis kelamin, luas lahan, modal usahatani, frekuensi penyuluhan, ketersediaan lembaga keuangan, peranan kelompok tani dan sosial budaya. Secara sistematis kerangka penelitian evaluasi penerapan panca usahatani padi ladang amfibi dapat digambarkan dalam Gambar 1 sebagai berikut: 


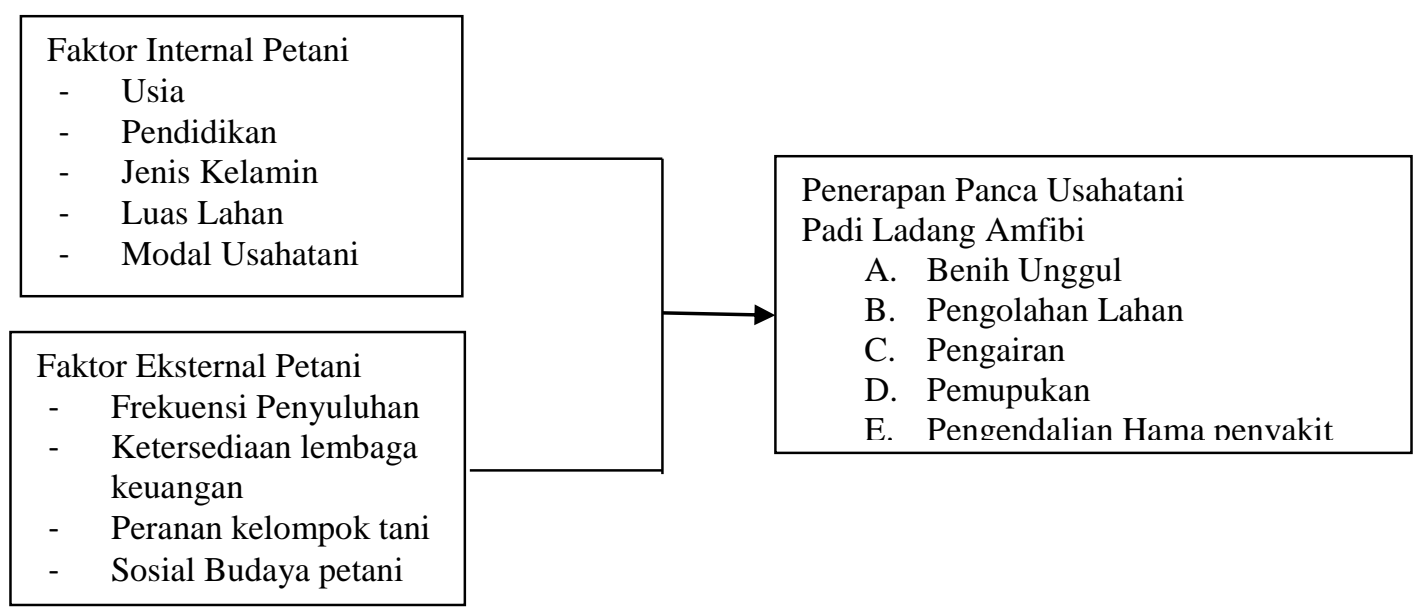

Keterangan garis: $\longrightarrow \quad=$ mempengaruhi

Gambar 1. Kerangka Penelitian Evaluasi Penerapan Panca Usahatani Padi Ladang amfibi pada Petani Binaan BPTP di Kabupaten Manokwari

\section{METODE}

\section{Waktu dan Tempat Penelitian}

Penelitian dilaksanakan selama 6 bulan pada tahun 2020. Tempat penelitian di 5 distrik di Kabupaten Manokwari, yaitu Distrik Manokwari Timur, Distrik Warmare, Distrik Prafi, Distrik Masni dan Distrik Sidey dengan pertimbangan lokasi petani binaan BPTP yang menanam padi ladang amfibi tersebar pada lima distrik tersebut.

\section{Sampel Penelitian}

Sampel penelitian adalah petani binaan BPTP yang menanam padi ladang amfibi. Pengambilan sampel responden dilaksanakan dengan metode sensus sebanyak 80 petani dengan perincian 20 petani di Distrik Manokwari Timur, 5 petani di Distrik Warmare, 31 petani di Distrik Prafi, 14 petani di Distrik Masni dan 10 petani di Distrik Sidey.

\section{Peralatan Penelitian}

Peralatan yang digunakan dalam penelitian adalah, a). kuesioner penelitian, b). kamera smartphone dan c). laptop dengan software IBM SPSS ver 20.

\section{Metode Penelitian}

Metode yang dipergunakan dalam penelitian adalah metode survei dengan studi kasus. Metode penelitian ini dirancang melalui langkah-langkah penelitian dari mulai menentukan kerangka penelitian, operasionalisasi variabel, penentuan jenis dan sumber data, metode pengumpulan data atau survei, model penelitian diakhiri dengan merancang analisis data dan pengujian hipotesis.

Penelitian dibutuhkan adanya suatu metode, cara atau taktik sebagai langkahlangkah yang harus ditempuh oleh seorang peneliti dalam tujuan. Teknik yang digunakan dalam penelitian ini adalah teknik survei yang dilaksanakan dengan mengambil sampel dari satu populasi dengan menggunakan kuesioner sebagai alat pengumpul data (Singarimbun dan Effendi, 1995). 


\section{Metode Analisis Data}

Guna menjawab tujuan penelitian digunakan metode analisis data yang sesuai. Metode analisis data yang digunakan dalam penelitian ini adalah analisis regresi logistik multinomial. Metode analisis regresi logistik multinomial adalah analisis regresi dengan banyak faktor penduga lebih dari 3 faktor. Metode ini dapat diartikan sebagai perhitungan yang mencari garis persamaan garis regresi dan menghitung korelasi antar variabel. Perhitungan korelasi parsial akan melelengkapi informasi data hasil penelitian (Nurgiyantoro, 2012).

\section{Model regresi multinomial dihitung menggunakan program SPSS 20. Analisis (2012).}

regresi multinomial ini dipilih karena model menggunakan variabel terikat (Y) yang merupakan penerapan panca usahatani yang berskala nominal dan melibatkan beberapa variabel bebas ( $\mathrm{x}$ ) berupa usia, pendidikan, jenis kelamin, luas lahan, modal usahatani, frekuensi penyuluhan, ketersediaan lembaga keuangan, peranan kelompok tani dan sosial budaya.

\section{HASIL DAN PEMBAHASAN}

Hasil analisis data menunjukkan bahwa rata-rata tingkat penerapan panca usahatani padi ladang amfibi diketahui sesuai dengan gambar histrogram berikut:

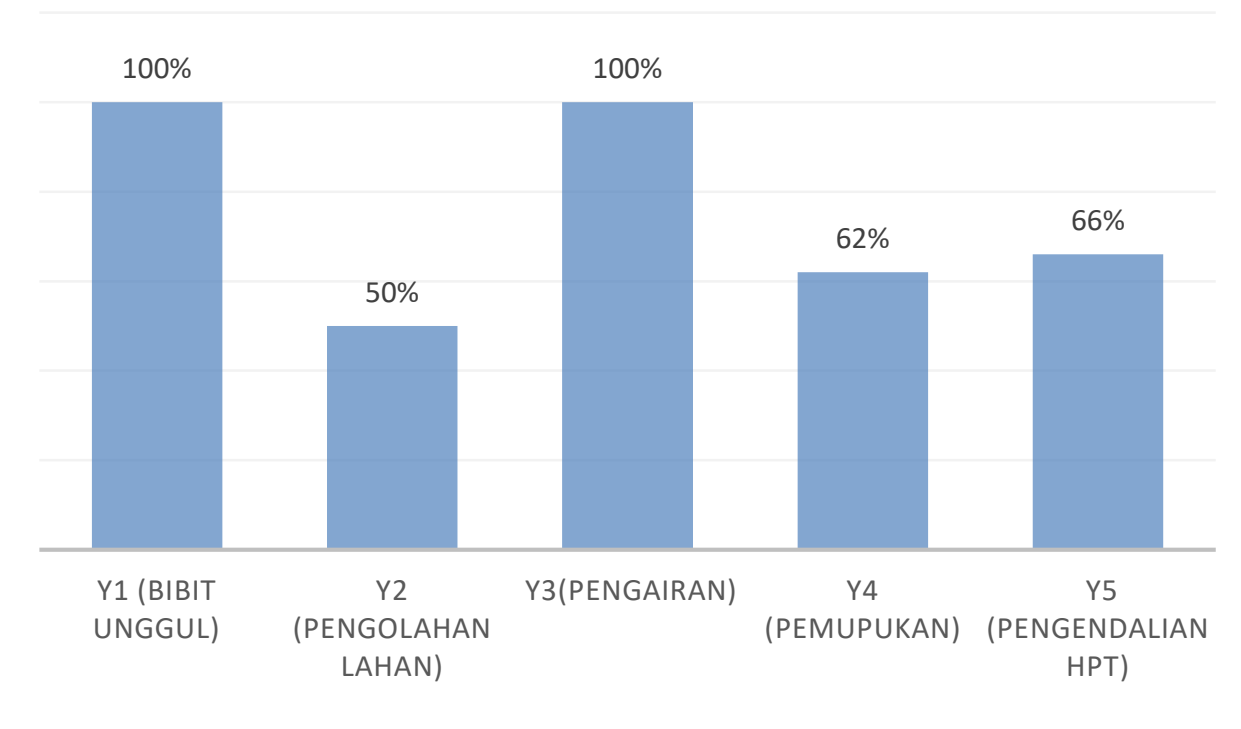

Gambar 2. Rata-Rata Penerapan Panca Usahatani Padi Ladang Amfibi

Komponen penggunaan benih unggul nilai rata-rata penerapan tertinggi yaitu $100 \%$ atau seluruh petani menerapkan komponen teknologi benih unggul. Benih unggul yang disediakan oleh BPTP Papua Barat yang merupakan benih unggul bersertifikat produk dari Balitbangtan sesuai kategori persyaratan benih berkualitas. Benih yang ditanam oleh petani responden seluruhnya merupakan jenis padi ladang amfibi, dengan varietas yaitu: Inpago 4, Inpago 8, Inpago 9, Inpago 11 dan Towuti.

Komponen pengolahan lahan memiliki tingkat penerapan sebagian oleh petani atau 
sesuai nilai $50 \%$ atau masuk kategori penerapan sedang karena menyesuaikan kondisi lahan petani. Sebagian besar lahan merupakan lahan bukaan baru dengan skala luasan terbatas dan terpencar sesuai pola tebang bakar yang berada di perbukitan. Petani beranggapan bahwa kesuburan lahan masih tinggi karena baru dibuka lahan dan kondisi humus yang masih tebal sehingga tidak dilakukan olah lahan sesuai rekomendasi. Selain hal tersebut petani juga kesulitan mengakses alat pengolahan lahan pertanian yang bersifat mobile atau dapat berpindah lokasi menyesuaikan topografi lahan petani. Pemberian nilai skoring dalam pengolahan lahan berdasarkan atas pengolahan lahan yang dilakukan di awal musim kemarau maupun pengolahan lahan pada awal musim tanam. Nilai skoring tertinggi diberikan bagi petani yang mengolah lahan lahan sebanyak dua tahap yaitu pada musim kemarau maupun di awal musim tanam.

Komponen pengairan yang menitikberatkan ketersediaan air sudah dipahami dan diterapkan sepenuhnya oleh seluruh petani responden dengan nilai skor $100 \%$. Seluruh petani sudah memahami bahwa salah satu faktor penentu keberhasilan usahatani padi ladang adalah ketercukupan air pada setiap fase pertumbuhan padi ladang berdasarkan pengalaman usahataninya. Kondisi lahan untuk penanaman padi ladang amfibi adalah lahan kering dan pemenuhan kebutuhan air diperoleh dari air hujan. Seluruh petani binaan yang menjadi dapat menjelaskan alasan kenapa padi ladang harus ditanam pada bulan ke 10 atau Bulan Oktober setiap tahunnya yaitu untuk ketercukupan air pada saat pertumbuhan padi ladang. Selain hal tersebut diketahui bahwa sebagian besar petani sudah dapat menghitung pada saat setelah panen kondisi cuaca sudah mulai kering sehingga memudahkan dalam proses panen dan penjemuran gabah. Pada komponen teknologi ini, seluruh petani sudah memahami dan menerapkan prinsip ketercukupan air sesuai fase pertumbuhan padi berdasarkan penentuan musim tanam sesuai pengalaman petani.

Komponen pemupukan yang diterapkan sebagian oleh petani dengan nilai skor $62 \%$. Tingkat penerapan pemupukan sesuai rekomendasi termasuk kategori sedang dikarenakan beberapa faktor sebagai berikut: kesuburan lahan, ketersediaan pupuk pada saat musim tanam padi ladang amfibi dan posisi lahan yang berada di atas perbukitan. Petani tidak seluruhnya menerapkan $3 \mathrm{~T}$ yaitu tepat dosis, tepat waktu dan tepat metode aplikasi karena tidak seluruh petani memahami penggunaan dan belum memiliki alat BWD ataupun PUTK. Rekomendasi pupuk yang digunakan Urea $250 \mathrm{~kg} / \mathrm{Ha}$, Phonska 250 kg/Ha, SP36 100 kg/Ha, KCl 100 kg/Ha (Pupuk Nitrogen berdasarkan BWD). Selain permasalahan tersebut, sebagian petani menyatakan bahwa penyediaan pupuk ditentukan dari RDKK (Rencana Definitif Kebutuhan Kelompok) yang diajukan oleh kelompok masing-masing. Pupuk yang dipergunakan oleh petani adalah pupuk NPK Phonska dan pupuk Urea sesuai dengan yang tersedia di tingkat kelompok petani atau di kios pertanian. Adapun jumlah dan dosis pemupukan tergantung pada modal usahatani yang dimiliki oleh petani. 
Komponen teknologi pengendalian HPT menjadi komponen yang diterapkan sebagian oleh petani dengan skor 66\%. Komponen pengendalian ini merupakan kegiatan yang pasti dilakukan oleh petani dalam menjaga usahataninya agar tetap memiliki hasil sesuai yang diharapkan. Sebagian petani melakukan pengendalian berdasarkan modal yang dimiliki, pengalaman dan kemampuannya dalam menyediakan obat insektisida maupun pestisida. Pengendalian seharusnya sesuai dengan rekomendasi dari petugas POPT (Pengawas Organisme Pengganggu Tanaman). Petani belum seluruhnya mengacu rekomendasi dari petugas POPT dalam pengendalian hama penyakit tanaman.

Faktor-faktor yang mempengaruhi penerapan panca usahatani padi ladang amfibi

Tabel. 1. Model Kriteria Kesesuaian Informasi

\begin{tabular}{lcccc}
\hline \multirow{2}{*}{ Model } & Model Fitting Criteria -2 & \multicolumn{2}{c}{ Likelihood Ratio Tests } & \\
\cline { 4 - 5 } & Log Likelihood & Chi-Square & df & Sig. \\
\hline Intercept Only & 84.936 & & & \\
Final & 44.509 & 40.427 & 14 & .000 \\
\hline
\end{tabular}

Dari tabel di atas diketahui bahwa nilai intercept only lebih besar dari nilai final. Yaitu $84.936>44.509$ dengan probabilitas $<0.05$ maka model signifikan dengan variabel independen (Var X) lebih akurat untuk memprediksi penerapan. Hasil perhitungan diperoleh nilai $\mathrm{P}$ value yang lebih kecil dari 0,05 sehingga dapat dikatakan dengan tingkat signifikansi 5\% terdapat cukup bukti bahwa minimal satu variabel independen mempengaruhi penerapan panca usahatani yang secara statistik mempengaruhi variabel dependen Y (penerapan panca usahatani). dapat diketahui melalui uji multinomial regresi untuk faktor-faktor yang diduga berpengaruh sesuai dengan hipotesa yang sudah disusun dalam kerangka penelitian. Penggunaan metode regresi multinomial ini karena adanya data nominal dan data ordinal pada variabel faktorfaktor yang akan diteliti. Adapun hasil analisis regresi multinomial dapat dilihat kesesuaian model pada faktor-faktor yang mempengaruhi penerapan panca usahatani padi ladang amfibi. Model kriteria kesesuaian informasi menunjukkan apakah dengan menambah variabel X ke dalam model dapat menjadi lebih baik atau tidak apabila dilihat dari $-2 \log$ likehood. Hasil perhitungan dari SPSS dapat diamati pada Tabel 1 sebagai berikut; 
variabel independen mampu menjelaskan keragaman data variabel dependen, adapun

Tabel 2. Nilai Hasil Pseudo R-Square

\begin{tabular}{cc}
\hline & Pseudo R-Square \\
\hline Cox and Snell & .397 \\
Nagelkerke & .596 \\
McFadden & .461 \\
\hline
\end{tabular}

Koefisien determinasi Psudo R.Square atau uji kebaikan model ini dapat memperhitungkan besarnya koefisien determinasi untuk melihat seberapa besar keragaman data variabel independen mampu menjelaskan keragaman data variabel dependen. Nilai Nagelkerke sebesar 0,596 menunjukkan bahwa keragaman data variabel bebas dalam penelitian mampu menjelaskan keragaman data variabel terikatnya sebesar $59,60 \%$, sedangkan sisanya dijelaskan oleh variabel yang ada di luar penelitian.

Selanjutnya untuk mengetahui masingmasing faktor yang mempengaruhi penerapan hasil yang diperoleh dan penjelasannya dapat diketahui dari Tabel 2 sebagai berikut: panca usahatani padi ladang amfibi dilakukan uji estimasi signifikansi parameter secara parsial. Uji estimasi parameter ini dapat melihat lebih terperinci masing-masing faktor yang diduga mempengaruhi dan dengan tingkat kepercayaan $\alpha$ : 0,05 atau 95\% dapat diketahui faktor-faktor yang berpengaruh terhadap model regresi multinomial. Variabel dengan nilai signifikansi $<0,05$ adalah variabel yang memberi kontribusi terhadap model. Adapun hasil dari pengujian ini dapat diketahui pada Tabel 3 berikut:

Tabel 3. Faktor-Faktor yang Mempengaruhi Model Regresi Multinomial

\begin{tabular}{lcccc}
\hline \multirow{2}{*}{ Effect } & $\begin{array}{c}\text { Model Fitting Criteria } \\
\text {-2 Log Likelihood of Reduced Model }\end{array}$ & \multicolumn{2}{c}{ Likelihood Ratio Tests } \\
\cline { 3 - 5 } & $44.509^{\mathrm{a}}$ & .000 & 0 & Shig. \\
\hline Intercept & 44.888 & .379 & 1 & .538 \\
Usia & 49.766 & 5.256 & 1 & .022 \\
Pend & 45.903 & 1.393 & 2 & .498 \\
Jen.Kel & 44.698 & .188 & 1 & .664 \\
LuasLhn & 50.906 & 6.397 & 2 & .041 \\
ModalUT & 55.829 & 11.319 & 2 & .003 \\
Frek.Peny & 52.764 & 8.254 & 1 & .004 \\
Ket.LemKeu & 46.374 & 1.865 & 2 & .394 \\
Per.KT & 51.836 & 7.326 & 2 & .026 \\
SosBud & & & & \\
\hline
\end{tabular}

Dari Tabel 3 diketahui terdapat 5 faktor yang berpengaruh signifikan terhadap model regresi multinomial pada tingkat kepercayaan $\alpha$ : 0,05 . Masing-masing faktor tersebut adalah faktor internal dan faktor eksternal. Untuk faktor internal yang berpengaruh terhadap model regresi multinomial adalah pendidikan $(0,022)$ dan modal usahatani $(0,041)$. Sedangkan faktor eksternal yang berpengaruh adalah frekuensi penyuluhan $(0,003)$, 
ketersediaan lembaga keuangan $(0,004)$ dan sosial budaya $(0,026)$ merupakan variabel yang signifikan berpengaruh terhadap model regresi multinomial.

Hasil analisis secara simultan diatas dapat diketahui bahwa sebagian besar petani tergolong dalam usia petani kategori usia produktif sebesar $90 \%$ dibandingkan dengan petani usia muda dan petani usia tua yang jumlahnya sebesar $10 \%$. Usia petani mempengaruhi penerapan panca usahatani padi ladang amfibi. Jumlah petani usia muda sangat sedikit dibandingkan dengan petani usia produktif. Hal ini dikarenakan generasi muda cenderung memilih pekerjaan di bidang lain yang hasilnya lebih cepat. Hasil penelitian dari Susilowati (2016) menunjukkan bahwa petani muda sudah semakin jarang ditemui karena ketertarikan pada dunia pekerjaan bidang pertanian yang rendah. Gambaran bahwa pertanian hanya terbatas kegiatan on farm mengakibatkan semakin menurun generasi muda yang terjun ke dunia pertanian

Kategori tingkat pendidikan petani yang paling banyak mempengaruhi penerapan adalah kategori pendidikan petani yang menengah yaitu sebesar $71,25 \%$ dari total petani. Hal ini terkait dengan kemampuan petani untuk memahami tentang materi penyuluhan dalam setiap komponen teknologi panca usahatani padi ladang amfibi. Hal tersebut sesuai dengan hasil penelitian dari Mardikanto (2018) yang menyatakan bahwa tingkat pendidikan petani yang mempengaruhi tingkat pemahaman petani dalam menganalisis permasalahan dan menentukan solusi yang akan diambil untuk memecahkan permasalahan. Termasuk dalam kegiatan penerapan padi ladang amfibi, petani dengan pendidikan menengah akan lebih aktif mencari solusi untuk memecahkan peramasalahannya.

Untuk meningkatkan pendidikannya, petani dapat dilakukan dengan cara kejar paket A atau B yang dilaksanakan oleh Kementerian Pendidikan dan Kebudayaan. Petani akan meningkat jenjang pendidikannya dan semakin tinggi pendidikan harapannya dapat membuka wawasan pengetahuan serta sikap petani terhadap teknologi padi amfibi yang diperkenalkan. Selain itu terdapat kegiatan sekolah lapang yang dapat meningkatkan pengetahuan dan keterampilan petani dalam menerapkan komponen teknologi padi ladang amfibi.

Jenis kelamin petani responden laki-laki dan perempuan tidak berpengaruh secara nyata terhadap penerapan panca usahatani padi ladang amfibi. Petani laki-laki cenderung menjalankan fungsi manajerial usahatani sebagai perencana dan pelaksana pada setiap tahapan komponen teknologi panca usahatani padi ladang amfibi.

Luas lahan yang paling banyak yang dimiliki oleh petani responden termasuk dalam kategori sedang sebesar 58,75\% karena dalam mengelola lahan petani masih membatasi lahan sesuai dengan tingkat kemampuan dalam mengolahnya. Hasil dari penelitian menunjukkan sebagian besar petani responden memiliki lahan yang sempit dan sedang karena kemampuan dan jumlah tenaga kerja dalam membuka hutan dengan sistem tebang bakar yang terbatas. Sedangkan kepemilikan lahan luas rata-rata adalah petani responden yang 
merupakan kepala kampung atau tokoh masyarakat setempat

Modal usahatani petani responden termasuk dalam kategori modal sedang sebesar $46,25 \%$ dibandingkan dengan petani yang memiliki modal rendah sebesar $31,25 \%$ dan petani yang memiliki modal tinggi sebesar $22,5 \%$. Modal usahatani berpengaruh signifikan terhadap penerapan panca usahatani padi ladang amfibi karena seluruh petani masih menggunakan modal usahatani yang bersumber dari modal pribadi. Masing-masing kelas penilaian dalam pemanfaatan modal berpengaruh karena komponen teknologi penerapan panca usahatani memerlukan saprodi yang hanya dapat dipenuhi dengan mengeluarkan modal usahatani. Masing-masing petani memiliki kemampuan modal usahatani yang berbeda yang dapat mengakibatkan tingkat penerapan usahatani yang berbeda pula. Petani dengan modal sedikit akan menerapkan komponen panca usahatani yang lebih rendah karena saprodi terbatas yang bisa diusahakan petani.

Petani responden yang menyatakan mengikuti penyuluhan sebanyak sekali sampai dengan tiga kali salam satu musim sebanyak $62,5 \%$ dari total responden. Petani dengan frekuensi mengikuti penyuluhan pertanian yang rutin memiliki tingkat penerapan panca usahatani lebih baik dibandingkan dengan petani yang lebih sering mengikuti penyuluhan pertanian. Frekuensi penyuluhan akan mempengaruhi tingkat adopsi pemahaman petani dalam menerapkan panca usahatani padi ladang amfibi menjadi lebih rendah. Hal tersebut sesuai dengan hasil penelitian Suprapto
(2010) menyatakan bahwa kegiatan penyuluhan terbukti memiliki pengaruh yang positif terhadap peningkatan produksi dan dapat meningkatkan pendapatan petani, sehingga perlu ditingkatkan frekuensi atau intensitas kegiatan penyuluhan bagi petani.

Penyuluh pertanian dapat meningkatkan kegiatan Laku (latihan dan kunjungan) kepada petani dalam wilayah binaanya. Kegiatan ini dapat ditingkatkan frekuensinya dan dituangkan dalam RKTP (Rencana Kerja Tahunan Penyuluhan Pertanian) masing-masing penyuluh. Koordinator penyuluh akan merekap kegiatan ke dalam sebuah dokumen programa penyuluhan pertanian di tingkat BPP (Balai Penyuluhan Pertanian). Programa penyuluhan ini akan menjadi dasar bagi penyuluh pertanian dalam mencapai target perubahan perilaku petani binaan di wilayah kerjanya masingmasing.

Ketersediaan lembaga keuangan mempengaruhi penerapan panca usahatani padi ladang amfibi. Hasil penelitian menujukkan bahwa $66,25 \%$ petani responden pada umumnya menyatakan bahwa terdapat lembaga keuangan tetapi persyaratan administrasi cukup rumit sehingga tidak mengakses lembaga keuangan untuk menjalankan usahatani padi ladang amfibi. Petani responden menyatakan bahwa persyaratan administrasi dalam mengakses lembaga keuangan mengakibatkan petani belum memanfaatkan program modal dari lembaga keuangan. Petani menyadari sepenuhnya bahwa dibalik persyaratan yang rinci dan rumit petani memiliki peluang untuk meningkatkan skala usahatani dan memperoleh pendapatan yang lebih baik. 
Petani responden sebanyak 53,75\% beranggapan bahwa kelompok tani hanya berperan dalam penyediaan saprodi. Petani yang tergabung dan aktif dalam kelompok tani akan memiliki akses yang mudah dalam pengadaan saprodi. Petani yang merasa kelompok tani dapat berperan dalam pengadaan saprodi akan menerapkan panca usahatani lebih baik. Organisasi petani menjadi salah satu unsur penting bagi petani dalam mengakses sumber permodalan. Permasalahan yang sering muncul dalam organisasi dan kelembagaan petani adalah tidak ada batasan yang jelas antara sosial dan bisnis (Hanggana, 2017). Pendapat tersebut terkait dengan petani responden yang meranggapan bahwa organisasi kelompok tani masih terbatas pada pengadaan saprodi dan pertukaran informasi. Pembinaan kelompok tani dapat meningkatkan peranan kelompok tani, khususnya dalam membantu petani mengakses sumber permodalan usahatani.

Faktor sosial budaya petani dengan dapat mempengaruhi penerapan panca usahatani padi ladang amfibi menjadi lebih tinggi. Petani ada yang melaksanakan sistem upah dalam menjalankan usahataninya sebesar $22,5 \%$ dari total responden. Penerapan sistem upah tenaga kerja ini biasanya dilaksanakan pada tahap olah lahan dan tahap panen yang membutuhkan tenaga kerja relatif lebih banyak. Sebagian besar petani masih menjalankan gotong royong yaitu sebesar $62,5 \%$ dari total responden.

Gotong royong akan meningkatkan semangat kerja masyarakat dan dapat langsung bertukar informasi serta pengalaman dalam penerapan panca usahatani padi ladang amfibi. Pendapat dari Anakotta et al., (2019) dapat memperjelas bahwa fenomena kegiatan gotong royong ini menunjukkan bahwa dalam struktur masyarakat sudah melebur dan lebih bersifat saling menghargai satu sama lain, sehingga kerjasama memungkinkan untuk terlaksana dengan baik dalam mencapai tujuan bersama.

$$
\text { Selanjutnya dilakukan pengujian }
$$
estimasi parameter yang merupakan bagian dari analisis regresi multinomial yang dapat dipergunakan untuk menduga parameter dari masing-masing faktor-faktor yang mempengaruhi penerapan panca usahatani padi ladang amfibi. Masing-masing parameter dapat diamati pada Tabel 4 sebagai berikut: 
Tabel 4. Estimasi Parameter Faktor yang Mempengaruhi Pada Penerapan Panca Usahatani Tingkat Sedang

\begin{tabular}{|c|c|c|c|c|c|c|c|}
\hline & Penerapan PUT $^{\mathbf{a}}$ & $\mathbf{B}$ & $\begin{array}{c}\text { Std. } \\
\text { Error }\end{array}$ & Wald & df & Sig. & $\operatorname{Exp}(B)$ \\
\hline \multirow{22}{*}{ 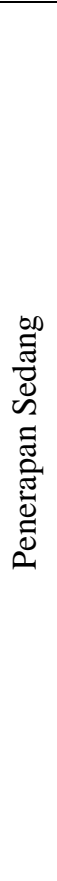 } & Intercept & 1.461 & 3.813 & .147 & 1 & .702 & \\
\hline & Usia & -.032 & .053 & .366 & 1 & .545 & .968 \\
\hline & LuasLhn & -2.725 & 1.330 & 4.202 & 1 & .040 & .066 \\
\hline & Pend rendah & 2.750 & 2.984 & .849 & 1 & .357 & 15.644 \\
\hline & Pend menengah & 2.901 & 2.733 & 1.127 & 1 & .288 & 18.191 \\
\hline & Pend tinggi & $0^{\mathrm{b}}$ & . & . & 0 & . & . \\
\hline & Petani Laki-laki & -1.507 & 3.522 & .183 & 1 & .669 & .221 \\
\hline & Petani Perempuan & $0^{\mathrm{b}}$ & . & 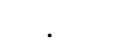 & 0 & . & . \\
\hline & Modal Usahatani rendah & -3.693 & 1.601 & 5.319 & 1 & .021 & .025 \\
\hline & Modal Usahatani Sedang & -.952 & 1.014 & .880 & 1 & .348 & .386 \\
\hline & Modal Usahatani tinggi & $0^{\mathrm{b}}$ & . & . & 0 & . & . \\
\hline & Tidak pernah mengikuti & 22.323 & .000 & 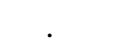 & 1 & . & 4950308835.7 \\
\hline & Penyuluhan 1 s/d 3 kali & -.137 & 1.325 & .011 & 1 & .918 & .872 \\
\hline & Penyuluhan lebih dari 4 kali & $0^{\mathrm{b}}$ & - & 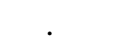 & 0 & . & 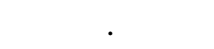 \\
\hline & Tidak ada lembaga keuangan & 3.849 & 1.653 & 5.421 & 1 & .020 & 46.939 \\
\hline & Ada lemb. keu, syarat rumit & $0^{\mathrm{b}}$ & 列 & 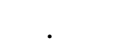 & 0 & . & . \\
\hline & Tidak ada peranan kel. tani & -.401 & 1.357 & .087 & 1 & .768 & .670 \\
\hline & KT berperan saprodi & -1.466 & 1.114 & 1.731 & 1 & .188 & .231 \\
\hline & KT berperan saprodi dan informasi & $0^{\mathrm{b}}$ & 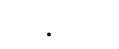 & 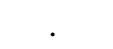 & 0 & . & . \\
\hline & Sistem upah kerja & 4.102 & 1.753 & 5.474 & 1 & .019 & 60.474 \\
\hline & Sistem gotong royong & 1.399 & 1.103 & 1.609 & 1 & .205 & 4.052 \\
\hline & Sistem Gotong royong dan sosial & $0^{\mathrm{b}}$ & & & 0 & & . \\
\hline
\end{tabular}

Keterangan: a. Referensi Kategori adalah Penerapan Tinggi

b. Parameter ini dirubah ke nilai 0 (nol) karena Redundant

Petani dengan luas lahan sedang memiliki nilai $\mathrm{B}=-2,725$ dan signifikan 0,040 $<0,050$. Nilai odd rasio sebesar 0,066 dapat diartikan bahwa kecenderungan dari petani responden dengan lahan sedang $(0,25 \mathrm{~s} / \mathrm{d} 1$ hektar) untuk menerapkan panca usahatani pada tingkat sedang adalah sebesar 0,066 lebih rendah daripada petani yang memiliki lahan lebih luas. Petani memiliki kemampuan untuk mengukur batas kemampuan dari segi tenaga dan waktu dalam mengelola lahan, termasuk dalam penerapan panca usahatani padi ladang amfibi. Penambahan luas lahan memerlukan tambahan tenaga dan dapat ditutupi dengan sistem upah kepada buruh petani dari peningkatan hasil produksi yang diterima petani. Hal tersebut sesuai dengan hasil penelitian Arimbawa dan Widanta (2017) yang menunjukkan bahwa untuk meningkatkan produksi dan produktivitas dapat diperoleh dengan penambahan luas lahan oleh petani.

Petani yang memiliki modal rendah memiliki nilai $\mathrm{B}=-3,693$ signifikan $0,021<$ 0,050. Nilai odd rasio sebesar 0,025 dapat diartikan bahwa kecenderungan dari petani responden yang memiliki modal rendah untuk menerapkan panca usahatani pada tingkat sedang adalah sebesar 0,066 lebih rendah daripada petani yang memiliki modal lebih tinggi. Petani dengan modal rendah akan kesulitan memenuhi rekomendasi jenis dan jumlah saprodi yang dipergunakan karena keterbatasan modal. Petani dapat menambah modal melalui pinjaman dari kelompok tani maupun dari lembaga keuangan atau perbankan. Simatupang

(2019), 
mengemukakan bahwa dalam mengakses pinjaman modal petani harus lebih selektif dalam memilih pinjaman karena terkait loyalitas petani sendiri atau kemampuan dalam mengembalikan modal pinjaman serta kualitas pelayanan yang diberikan lembaga keuangan atau perbankan yang berbeda satu sama lain.

Petani yang beranggapan tidak ada lembaga keuangan memiliki nilai variabel $\mathrm{B}=$ 3,849 , signifikan $0,020<0,050$. Nilai odd rasio sebesar 46,939 dapat diartikan bahwa kecenderungan dari petani responden yang beranggapan tidak ada lembaga keuangan di wilayah sekitarnya akan menerapkan panca usahatani pada tingkat sedang adalah sebesar 46,939 lebih tinggi daripada petani lain yang merasa terdapat lembaga keuangan di wilayah sekitarnya.

Permasalahan lembaga keuangan di tingkat petani dapat diatasi dengan adanya penguatan dan pelatihan administrasi bagi kelompok tani ataupun gabungan kelompok tani (gapoktan). Kelompok tani dan gapoktan yang maju akan memperoleh bantuan dari pemerintah daerah dan dapat dipergunakan oleh petani untuk mengakses pinjaman modal usahatani padi. Hasil kajian dari Sutisna dan Motulo (2016) menyatakan bahwa peningkatan modal petani melalui lembaga keuangan mikro agribisnis (LKMA) dapat meningkatkan produksi dan secara tidak langsung dapat meningkatkan kesejahteraan petani.

Hal tersebut di atas selaras dengan hasil penelitian Simatupang (2019) bahwa komoditas padi merupakan komoditi yang memiliki nilai ekonomi yang tinggi dan dapat dikembangkan dengan menambah investasi pinjaman dari lembaga keuangan. Semakin tinggi modal petani maka tingkat produksi produksi dan produktivitasnya akan meningkat. Kementerian Pertanian juga mendorong adanya fasilitas Kredit Usaha Rakyat (KUR) yang tertuang dalam Permentan Nomor 16 Tahun 2018 Tentang Fasilitasi KUR Sektor Pertanian. Regulasi ini diharapkan dapat menjadi dasar yang menguatkan petani dalam mengakses KUR.

Petani yang beranggapan tidak adanya gotong royong memiliki nilai $\mathrm{B}=4,102$, signifikan $0,019<0,050$. Nilai odd rasio sebesar 60,474 dapat diartikan bahwa kecenderungan dari petani yang beranggapan tidak ada gotong royong di wilayah sekitarnya akan menerapkan panca usahatani pada tingkat sedang adalah sebesar 60,474 lebih tinggi daripada petani lain yang merasa masih terdapat gotong royong di wilayah sekitarnya. Gotong royong antara petani dapat ditingkatkan dengan penyelenggaraan kegiatan bersama sebelum pembukaan lahan, penanaman dan pemanenan padi. Pada kegiatan tersebut dapat juga dilaksanakan sesuai dengan agama dan keyakinan masing-masing petani dalam satu wilayah. Kegiatan ini akan mendorong kerjasama dalam arti positif guna meringankan petani tentang pemenuhan tenaga kerja.

Hasil rangkaian uji regresi multinomial secara simultan dapat menjawab hipotesis ketiga tentang faktor-faktor apa sajakah yang berpengaruh dalam penerapan panca usahatani padi ladang amfibi di Kabupaten Manokwari yaitu sebagai berikut tersebut adalah faktor internal yang terdiri dari pendidikan dan modal usahatani. Sedangkan faktor eksternal yang 
berpengaruh adalah frekuensi penyuluhan, ketersediaan lembaga keuangan dan sosial budaya.
Estimasi parameter faktor yang mempengaruhi penerapan panca usahatani pada penerapan put tinggi dapat dilihat pada Tabel 5 berikut:

Tabel 5. Estimasi Parameter Faktor yang Mempengaruhi Penerapan Panca Usahatani pada Penerapan PUT Tinggi

\begin{tabular}{|c|c|c|c|c|c|c|c|}
\hline & Penerapan PUT ${ }^{\mathbf{a}}$ & B & $\begin{array}{c}\text { Std. } \\
\text { Error }\end{array}$ & Wald & df & Sig. & $\operatorname{Exp}(B)$ \\
\hline \multirow{22}{*}{ 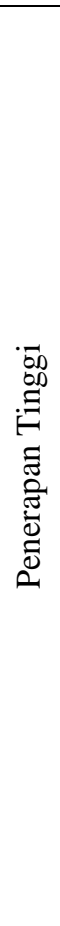 } & Intercept & 2.351 & 3.232 & .125 & 1 & .608 & \\
\hline & Usia & -.052 & .055 & .334 & 1 & .588 & .972 \\
\hline & LuasLhn & -2.725 & 1.330 & 4.202 & 1 & .640 & .066 \\
\hline & Pend rendah & 2.980 & 2.754 & .876 & 1 & .476 & 16.664 \\
\hline & Pend menengah & 4.601 & 2.733 & 1.127 & 1 & .024 & 19.292 \\
\hline & Pend tinggi & $0^{\mathrm{b}}$ & 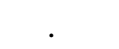 & & 0 & 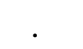 & 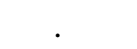 \\
\hline & Petani Laki-laki & -3.502 & 3.662 & .165 & 1 & .678 & .321 \\
\hline & Petani Perempuan & $0^{\mathrm{b}}$ & 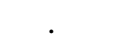 & . & 0 & . & 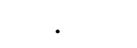 \\
\hline & Modal Usahatani rendah & -3.693 & 1.601 & 5.319 & 1 & .721 & .034 \\
\hline & Modal Usahatani Sedang & -.952 & 1.014 & .880 & 1 & .448 & .386 \\
\hline & Modal Usahatani tinggi & $0^{\mathrm{b}}$ & 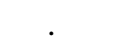 & . & 0 & . & . \\
\hline & Tidak pernah mengikuti & -2.323 & 1.654 & 4.852 & 1 & .864 & .457 \\
\hline & Penyuluhan $1 \mathrm{~s} / \mathrm{d} 3 \mathrm{kali}$ & 3.132 & 1.325 & .011 & 1 & .036 & 8.872 \\
\hline & Penyuluhan lebih dari 4 kali & $0^{\mathrm{b}}$ & & 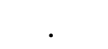 & 0 & 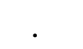 & 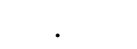 \\
\hline & Tidak ada lembaga keuangan & 2.842 & 2.655 & 4.422 & 1 & .320 & 46.939 \\
\hline & Ada lemb. keu, syarat rumit & $0^{\mathrm{b}}$ & 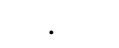 & 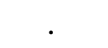 & 0 & 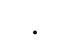 & . \\
\hline & Tidak ada peranan kel. tani & -.503 & 1.288 & .098 & 1 & .882 & .720 \\
\hline & KT berperan saprodi & -2.446 & 1.234 & 1.642 & 1 & .198 & .351 \\
\hline & $\begin{array}{l}\text { KT berperan saprodi dan } \\
\text { informasi }\end{array}$ & $0^{\mathrm{b}}$ & . & 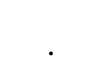 & 0 & . & . \\
\hline & Sistem upah kerja & 4.211 & 1.654 & 5.234 & 1 & .321 & 6.332 \\
\hline & Sistem gotong royong & 3.529 & 1.402 & 1.523 & 1 & .235 & 5.487 \\
\hline & Sistem Gotong royong dan sosial & $0^{\mathrm{b}}$ & 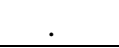 & 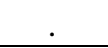 & 0 & . & . \\
\hline
\end{tabular}

Keterangan :

a. Referensi Kategori adalah Penerapan Sedang

b. Parameter ini dirubah ke nilai 0 (nol) karena Redundant

Petani dengan pendidikan menengah sedang memiliki nilai $\mathrm{B}=4,601$ dan signifikan $0,024<0,050$. Nilai odd rasio sebesar 19,292 dapat diartikan bahwa kecenderungan dari petani pendidikan menengah untuk menerapkan panca usahatani pada tingkat sedang adalah sebesar 19,292 lebih tinggi daripada petani yang memiliki pendidikan tinggi. Petani dengan pendidikan menengah menjalankan usahatani akan berupaya lebih keras untuk berhasil atau dapat memenuhi kebutuhan keluarganya. Petani dengan pendidikan menengah akan lebih mudah memahami rekomendasi teknologi panca usahatani dan mau menerapkannya langsung.

Petani yang memiliki yang mengikuti penyuluhan sebanyak 1 s/d 3 kali dalam satu musim memiliki nilai $\mathrm{B}=3,132$ signifikan $0,036<0,050$. Nilai odd rasio sebesar 8,872 dapat diartikan bahwa kecenderungan dari petani yang memiliki mengikuti penyuluhan 1 s/d 3 kali untuk menerapkan panca usahatani 8,872 kali lebih tinggi daripada petani yang tidak pernah mengikuti penyuluhan. Hal 
tersebut ssesuai dengan pendapat Narti (2015) bahwa terdapat hubungan yang signifikan antara frekuensi mengikuti penyuluhan pertanian dengan efektivitas komunikasi pertanian antara penyuluh dengan petani untuk meningkatkan produktivitas.

\section{KESIMPULAN DAN SARAN}

Penerapan pancausahatani padi ladang amfibi di Kabupaten Manokwari masih pada tingkat kategori sedang hal ini karena dipengaruhi oleh faktor-faktor pendidikan, modal usahatani, frekuensi penyuluhan, ketersediaan lembaga keuangan dan sosial budaya.

Perlu adanya upaya peningkatan penerapan panca usahatani padi ladang amfibi dari penerapan kategori sedang ke penerapan kategori tinggi di Kabupaten Manokwari dengan cara memacu pendidikan, modal usahatani, frekuensi penyuluhan, ketersediaan lembaga keuangan dan sosial budaya. Program kerja nyata yang dapat dilaksanakan untuk memacu faktor yang berpengaruh dalam penerapan panca usahatani padi ladang amfibi. Pendidikan petani dapat ditingkatkan dengan program kejar paket dan sekolah lapang tentang budidaya pertanian khususnya tentang penerapan panca usahatani padi ladang amfibi. Modal usahatani dapat ditingkatkan dengan adanya program Kredit Usaha Rakyat (KUR) yang kerjasama dengan lembaga keuangan pemerintah atau perbankan. Frekuensi penyuluhan dapat ditingkatkan melalui peningkatan frekuensi pertemuan atau melalui sistem laku oleh penyuluh pertanian. Kegiatan ini sebaiknya tertuang dalam Programa
Penyuluhan di tingkat distrik atau Balai Penyuluhan Pertanian (BPP) dan menjadi pedoman bagi penyuluh dalam menyusun Rencana Kerja Tahunan Penyuluhan (RKTP). Ketersediaan lembaga keuangan ditingkatkan dengan program pelatihan bagi gapoktan atau kelompok tani sebagai lembaga keuangan mikro untuk usaha agribisnis (LKMA) di tingkat pedesaan. Peningkatan faktor sosial budaya petani ditingkatkan melalui penyelenggaaan kegiatan sosial keagamaan secara bersama-sama pada tahap awal penanaman maupun pada saat panen raya.

\section{DAFTAR PUSTAKA}

Anakotta, R., Alman \& Solehun. (2019). Akulturasi Masyarakat Lokal dan Pendatang di Papua Barat. Jurnal Antropologi: Isu-Isu Sosial Budaya. Vol. 21 No. 01.

Arimbawa, P.D. \& Widanta, A.B.P. (2017). Pengaruh Luas Lahan, Teknologi dan Pelatihan terhadap Pendapatan Petani Padi dengan Produktivitas Sebagai Variabel Intervening di Kecamatan Mengwi. E-Jurnal Ekonomi Pembangunan. Vol. 6 No 8.

Badan Pusat Statistik. (2018). Provinsi Papua Barat Dalam Angka 2018. Badan Pusat Statistik Provinsi Papua Barat. Manokwari.

Hanggana, S. (2017). Analisis Kelemahan Regulasi Poktan, Gapoktan, Upja, Dan Lkm-A Dalam Peningkatan Pendapatan Petani. Jurnal Analisis Kebijakan Pertanian. Vol. 15 No. 2.

Konyep, S. \& Hidayat, G.W. (2017). Potensi Pengembangan Padi Ladang Ampibi di Kabupaten Manokwari. Prosiding Seminar Nasional. BPTP Sulawesi Utara.

Mardikanto, T. (2018). Penyuluhan Pembangunan. Sebelas Maret University Press. Surakarta. 
Narti, S. (2015). Hubungan Karaktersitik Petani Dengan Efektivitas Komunikasi Penyuluhan Pertanian Dalam Program SLPTT (Kasus Kelompok Tani di Kecamatan Kerkap Kabupaten Bengkulu Utara). Jurnal Profesional FIS UNIVED Vol 2 No 2.

Nurgiyantoro, B., Gunawan \& Marzuki. (2012). Statistik Terapan Untuk Penelitian IlmuIlmu Sosial. Gadjah Mada University Press. Yogyakarta.

Simatupang, D.O. (2019). Pinjaman Modal Usaha Tani Pada Bank Daerah Versus Bank Negara. Jurnal Ilmu Ekononomi dan Sosial. Vol. 10 No 2.

Singarimbun, M. \& Effendi, S. (1995). Metode Penelitian Survey. Penerbit Lembaga Penelitian, Pendidikan dan Penerangan Ekonomi dan Sosial (LP3ES). Jakarta.

Sitohang, F.R.H, Siregar, L.A.M., \& Putri, L.A.P. (2014). Evaluasi Pertumbuhan dan Produksi Beberapa Varietas Padi Ladang (Oriza Sativa L) Pada Beberapa Jarak Tanam Yang Berbeda. Jurnal Online Agroekoteknologi. Vol. 2 No. 2: 661-679.

Suprapto, E. (2010). Analisis Faktor-Faktor Yang Mempengaruhi Usahatani Padi Organik di Kabupaten Sragen. Tesis. Fakultas Ekonomi Universitas Sebelas Maret Program Pascasarjana Magister Ekonomi Dan Studi Pembangunan Surakarta.

Susilowati, S.H. (2016). Fenomena Penuaan Petani dan Berkurangnya Tenaga Kerja Muda serta Implikasinya bagi Kebijakan Pembangunan Pertanian. Jurnal Forum Penelitian Agro Ekonomi. Vol. 34 No. 1: 35-55.

Sutisna, E. \& Motulo, H.F.J. (2016). Analisis dampak Kinerja Kelompok Tani terhadap Pendapatan Usaha Tani Padi di Kabupaten Manokwari Selatan, Provinsi Papua Barat. Jurnal Pengkajian dan Pengembangan Teknologi Pertanian. 19 (1): 35-47. 